\title{
Nutritional Quality and SafetyAssessment of Complementary Food Produced from Acha (Digitaria exilis) Flour and Kariya (Hildergardia barteri) Protein Concentrate Blends
}

\author{
Abiodun Victor Ikujenlola*, Adedoyin Fikayo Ahmida and Olasunkanmi Saka Gbadamosi
}

Department of Food Science and Technology, Obafemi Awolowo University, Ile-Ife, Nigeria

Correspondence to:

Abiodun Victor Ikujenlola

Department of Food Science and Technology Obafemi Awolowo University, Ile-Ife, Nigeria

Tel: +2348033843674

E-mail: avjenlola@gmail.com

Received: August 11, 2016

Accepted: January 20, 2017

Published: January 24, 2017

Citation: Ikujenlola AV, Ahmida AF, Gbadamosi OS. 2017. Nutritional Quality and Safety Assessment of Complementary Food Produced from Acha (Digitaria exilis) Flour and Kariya (Hildergardia barteri) Protein Concentrate Blends. J Food Chem Nanotechnol 3(1): 24-30.

Copyright: (C) 2017 Ikujenlola et al. This is an Open Access article distributed under the terms of the Creative Commons Attribution 4.0 International License (CC-BY) (http:// creativecommons.org/licenses/by/4.0/) which permits commercial use, including reproduction, adaptation, and distribution of the article provided the original author and source are credited.

Published by United Scientific Group

\section{Abstract}

Complementary food is the intermediate food given to infant alongside with breast milk. This study is aimed at producing complementary foods from blends of acha flour and kariya protein concentrate.

Acha flour was produced from cleaned and milled raw acha. Raw kariya was processed to flour and protein concentrate flour. These flours were blended at 80:20 (acha: kariya). The nutritional qualities of the products were assessed using animal feeding experiment. The protein quality parameters and safety of the blends to the experimental animal were monitored. Data obtained were analyzed using appropriate descriptive and inferential statistics.

The result showed that the feed intake ranged between 104.46 and 196.86 $\mathrm{g} / \mathrm{rat} / 28$ days. There were significant differences $(\mathrm{p} \geq 0.05)$ in growth rates of the animals. Growth of the animals fed with acha blended with processed kariya ceased after the 13th day, while the other groups progressed with varied degrees of increase in weights. The Protein Efficiency Ratio (-1.55 to 1.85), Food Efficiency Ratio (-0.24 to 0.28), True Digestibility (54.26 to 62.89\%) and Net Protein Retention (-4.04 to 1.00) of the experimental animals varied with the diets. The mortality rate of $100 \%$ was recorded for diets containing acha and processed kariya after the $13^{\text {th }}$ day of the experiment.

Despite the high nutritional value and decrease in anti-nutrients contents of kariya after series of processing, the blends were still toxic to the experimental animals (all the animals fed with samples containing kariya died). The kariya containing diets may not be safe for infant consumption.

\section{Keywords}

Food intake, Growth rate, Mortality rate, Protein efficiency ratio, Toxic

\section{Introduction}

The period of complementary feeding has been defined as a transitional phase during which food other than mother's milk is expected to supply increasing proportion of a child's nutritional requirement [1]. Large numbers of infants and young children in developing countries suffer from the short and long-term health effects of poor breastfeeding and complementary feeding practices which in turn impact negatively on social and economic development [2]. In Africa, high prevalence of protein energy malnutrition among infants above six months old has been recorded $[2,3]$.

Many traditional complementary diets are mainly based on plants; cereals, or roots, and the large amounts of starches in these plant sources result in a thick, gelatinous porridge, which often has a low nutrient content [4]. In addition, mineral bioavailability is poor in many plant-based foods [5]. However, these 
traditional complementary foods could be improved by combining locally available plant based foods that complement each other in such a way that new patterns of amino acids are created [6]. Enrichment of cereal-based food with other protein source such as legumes, oilseeds etc, have received considerable attentions since investigations have revealed that cereals are deficient in lysine and tryptophan but have sufficient sulphurcontaining amino acids which are limiting in legumes [7]. In view of these nutritional challenges, quite a number of studies have investigated ways of formulating quality complementary foods through a combination of available plant based foods to meet the nutritional demands of infants of weaning age [6-18].

Despite all these interventions, it is quite evident that the objective of these efforts which was to develop low-cost foods is still far from being met. These products are still not available to poor families and therefore had little impact on the prevalence of child malnutrition [19].

As a means of addressing this problem, the present study is focused on the utilization of locally available nutritious and lesser known food materials acha and kariya to develop high dense nutrient and low-cost complementary foods.

Acha (fonio), a tropical millet native to West Africa, one of the most nutritious of all grains [20]; rich in methionine and cystine, amino acids vital to human health and deficient in today's major cereals [21]; has the advantage to be minimally processed which limited the loss of the native nutritional value during milling [20]. The use of $a c h a$ is mainly limited to traditional foods such as thick and thin porridges, steam cooked products (e.g. Couscous), and alcoholic and nonalcoholic beverages [21]. Acha can be used for complementary foods of low dietary bulk and high calorie density. Such complementary preparations with good acceptability and tolerance by children have been investigated [11, 13, 18, 22].

Kariya (Hildegardia barteri) primarily an ornamental tree in West Africa [23] whose flowers, which are usually borne on leafless branches, mature into one-seeded pods [24]. The mature pods drop completely when dry and are disposed as refuse in many places, only in few parts of West Africa the kernels are eaten raw or roasted like peanuts [25] or used as condiments in traditional food preparations. The essential amino acid pattern as reported by Inglett et al. [25] showed that the seeds are high in lysine; therefore the use of the meal as complement to cereal grain would be beneficial in improving the amino acid balance.

The use of a combination of acha and kariya concentrate has not been investigated as a possibility of producing a veritable complementary food for infants in the developing countries. Therefore, this study aimed at producing complementary diets from blends of acha and kariya protein concentrate and assessment of the proximate composition, physicochemical and functional properties of the products.

\section{Materials and Methods}

\section{Materials}

Acha grains were purchased from Abuja central market, Abuja. Dried kariya pods were gathered from ornamental kariya trees in Obafemi Awolowo University, Ile-Ife, Nigeria. All reagents used were of analytical grade and were obtained from Sigma Aldrich chemical company, USA.

\section{Production of acha flour}

The ach a grains were weighed $(1.00 \mathrm{~kg})$, washed thoroughly to remove dirt's, oven dried at $60{ }^{\circ} \mathrm{C}$ for $12 \mathrm{hrs}$ and milled into flours [18].

\section{Production of raw and defatted fermented kariya flours}

The kariya nuts extracted from the dried pods were sorted to remove extraneous materials such as stones and leaves. The kernels were obtained by shelling the nuts manually which were then cleaned to remove chaff, broken, shriveled and immature kernels. The cleaned raw kariya kernels were divided into two portions. One portion was oven dried for $12 \mathrm{hrs,} \mathrm{milled} \mathrm{and}$ sieved through $200 \mu \mathrm{m}$ sieve to produce the raw kariya flour. The second portion was soaked for $24 \mathrm{~h}$, cooked at $100{ }^{\circ} \mathrm{C}$ for $30 \mathrm{~min}$, drained and allowed to ferment (in a calabash lined with clean plantain leaves at ambient temperature) for a period of 4 days followed by oven-drying at $60^{\circ} \mathrm{C}$ for $20 \mathrm{hrs}$. The dried fermented seeds were comminuted using mortar and pestle to obtain coarse flour. The coarse flour obtained was then ground using Marlex Excella grinder (Marlex Appliances PVT., Daman) and sieved through $200 \mu \mathrm{m}$ sieve. The resulting flour was defatted using food grade hexane solvent in soxhlet extractor to obtain defatted fermented kariya flour. The defatted fermented flour was desolventized by drying in a fume hood and the dried fermented flour was finally ground in a Marlex Excella grinder (Marlex Appliances PVT., Daman) to obtain homogenous defatted fermented flour [26].

\section{Production of protein concentrate}

Kariya protein concentrate was produced according to the method described by Cheftel et al. [26] and modified by Gbadamosi et al. [27] as shown in Figure 1.

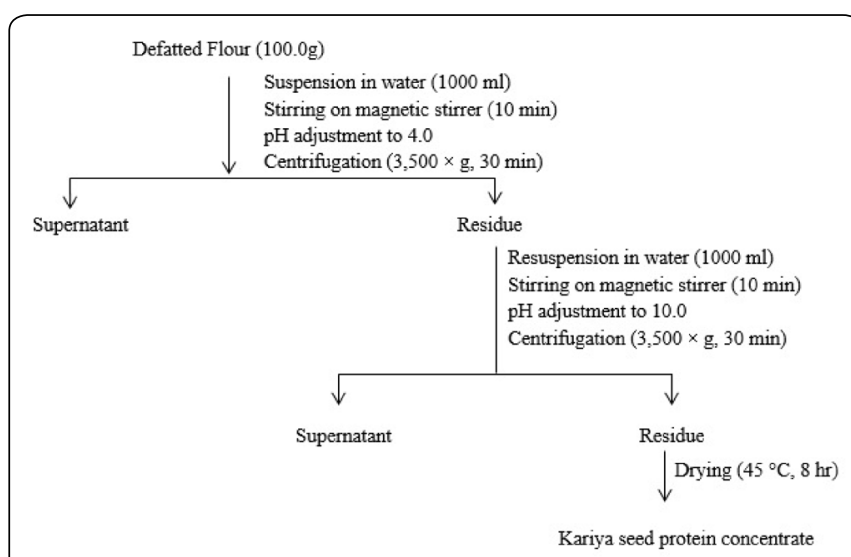

Figure 1: The production of kariya protein concentrate. Source: Cheftel et al.[26] and modified by Gbadamosi et al.[27].

\section{Formulation of the complementary food blends}

The dietary blends (Table 1 ) were formulated with a target protein of $20 \%$ in accordance to the recommendation of the World Health Organization [28, 29]. 
Table 1: Formulation of complementary food blends.

\begin{tabular}{|l|l|}
\hline Diet Sample & Formulation \\
\hline ASD & $100 \%$ Acha \\
\hline ACD & $80 \%$ Acha $+20 \%$ kariya Protein Concentrate \\
\hline ARD & $80 \%$ Acha $+20 \%$ Raw kariya Flour \\
\hline ABD & Basal (non-protein diet) $[4]$ \\
\hline AED & Commercial Diet (Control) \\
\hline
\end{tabular}

\section{Production of pre-gelatinized formulated diets}

The dietary blends were mixed and pre gelatinized by cooking at $100{ }^{\circ} \mathrm{C}$ for $10 \mathrm{~min}$. The pre-gelatinized blend was dried in an oven at $110{ }^{\circ} \mathrm{C}$ for $12 \mathrm{~h}$ and milled using attrition mill [30] as shown in Figure 2.

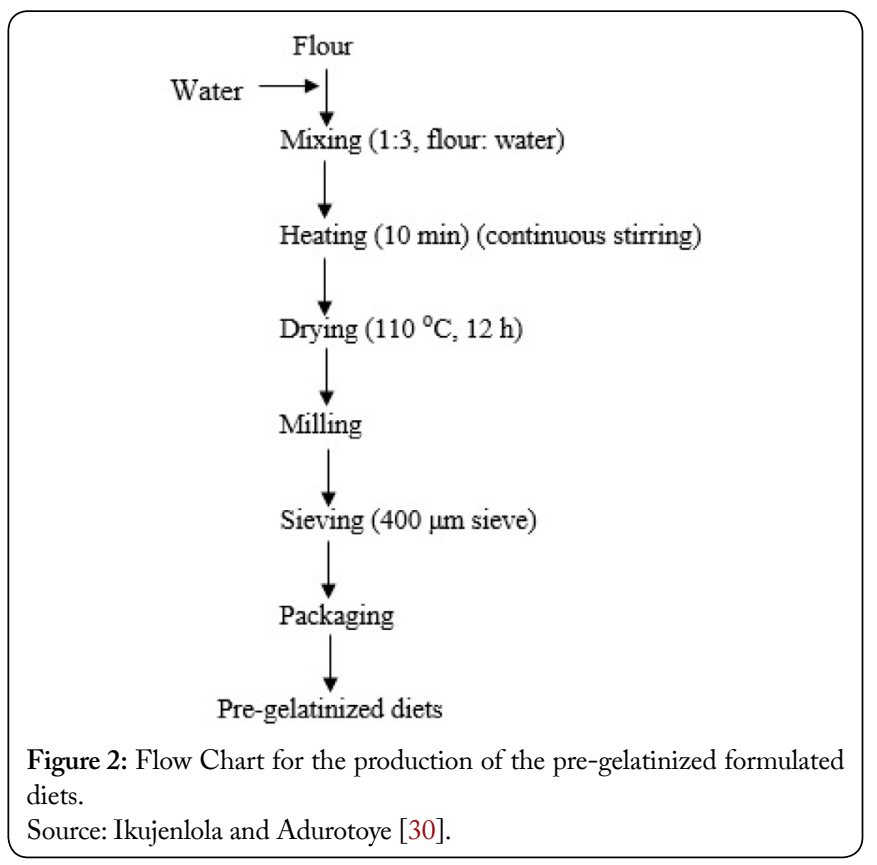

\section{Biological assessments}

The method of Ikujenlola and Fashakin [4] was adopted. For this study, albino weanling rats of both sexes of varying weight were obtained from the Animal House, Faculty of Health Sciences, Obafemi Awolowo University, IleIfe. Animals were weighed and randomly distributed into individual metabolic cages and then acclimatized for 5 days. The animals were re-weighed and divided into groups. The average weight per group was approximately the same. A group of the animals (zero-day animal) served as control for the experimental groups and were sacrificed; the liver, kidney, and the plantaris muscle of the hind-leg were removed, weighed and frozen for chemical analysis. The remaining animals were fed the experimental diets and water ad-libitum over a period of twenty eight days. During this period, dietary intake and growth were monitored. The fecal discharge and urine were collected as from the fourteenth to the last day of the experiment and kept for nitrogen analysis. At the completion of the experiment, the animals were anesthetically sacrificed. Data collected during the experiment were used in determining protein quality parameters (Protein Efficiency
Ratio (PER), Food Efficiency Ratio (FER), True Digestibility (TD), Net Protein Retention (NPR) and Protein Retention Efficiency (PRE). The study was carried out according to the rules of the Departmental ethics committee on animal studies/researches which is part of the University committee on animal researches.

$$
\begin{aligned}
& \text { PER }=\frac{\text { Weight gained }}{\text { Protein consumed }} \\
& F E R=\frac{\text { Weight gained }}{\text { Food consumed }} \\
& T D=\frac{N i-(N F 1-N F 2)}{N i} \times 100
\end{aligned}
$$

$\mathrm{Ni}=$ Nitrogen intake of animal fed with test diet, $\mathrm{NF}_{1}=$ Nitrogen excreted feces of animal fed test diet, $\mathrm{NF}_{2}=$ Nitrogen excreted from feces of animals fed protein free diet

$$
\mathrm{NPR}=\frac{\text { Weight gain of the test group }+ \text { Weight loss of protein free groups }}{\text { Weight of test protein consumed }}
$$

$\mathrm{PRE}=\mathrm{NPR} \times 16$

\section{Statistical analysis}

All determinations were made in triplicate and the data generated were subjected to one-way analysis of variance at $5 \%$ level of significance using SPSS 20.0 for Windows. Means were separated by Duncan's multiple range tests.

\section{Results and Discussion}

\section{Food intake of the experimental animals during feeding} experiment

The results showed that the mean food intake (Table 2) of the experimental animals fed on various formulated blends and the control varied from $104.46 \mathrm{~g}$ (basal diet) to $196.86 \mathrm{~g}$ (commercial diet). During the feeding experiment, it was observed that the rates and quantity of blend consumed varied not only between groups but also within the group. The protein intake of the animal followed a similar trend as the food intake, because the more the diet consumed, the more the protein (excluding basal). This agrees with the report of Vavidel and Pugalenthi [31] that placed the experimental animals (albino rats) on $20 \%$ protein.

\section{Growth performance of the experimental animals}

The growth performance of the experimental animals fed with the formulated complementary diets and control diet is presented in Figure 3. The mean weight gain (Table 2) ranged between $-25.44 \mathrm{~g}$ (Basal) and $55.72 \mathrm{~g}$ (commercial diet). It was observed that the weight of the experimental animals decreased after 4 days into the feeding exercise; this could be as a result of adjustment to the test feed by the animal. Commercial diet supported the best weight gain/growth among all the complementary diets while the basal diet 
supported least weight gain. The increase in weight gained was largely influenced by the quality of the protein constituents of the diet. The protein content of the raw, processed kariya and diet are reported in another study underway. Protein is required among other things for good growth, healthy living, maintenance and production of cell and tissues of the body [7]. There were significant differences $(p \leq 0.05)$ in the growth rates of the animals fed with the commercial diets and the formulated diets. The weight of animals fed on basal diet and ASD decreased as the feeding experiment progressed. This might be connected with the lack of protein in the basal diet but which is present in varying degrees in other samples. The basal diet and ASD did not support the growth; it was a negative growth rate (i.e. decline in growth rate), this was due to the fact that the basal diet lacks protein and ASD is deficient in some essential amino acids like lysine which is responsible for good growth and development. Low protein diets result in protein deficiency in weanling rats, which causes reduced growth, muscular wasting, emaciation and death if sufficiently severe [20]. All the animals that depend on the formulated diet for survival were found to become leaner and weaker each passing day of the experiment. Loss of weight were dramatic from $66.90 \mathrm{~g}$ and $66.92 \mathrm{~g}$ at day one to $41.46 \mathrm{~g}$ and $51.04 \mathrm{~g}$ at the twenty-eighth day for basal and ASD respectively.

On the other hand, the animals fed with other formulated diets i.e. ACD and ARD drastically reduced in weight from $66.78 \mathrm{~g}$ and $66.38 \mathrm{~g}$ at day one to $35.35 \mathrm{~g}$ and $37.50 \mathrm{~g}$ at $13^{\text {th }}$ day. The two groups ceased to exist after the $13^{\text {th }}$ day of the experiment i.e. all the animals fed with fortified kariya diets died. Although kariya flour and concentrate were high in protein but its inclusion did not support growth; the animals reduced in weight and eventually died. The death of the animals fed with kariya containing diets suggested that the diets possibly contained injurious substances apart from those analyzed under anti-nutritional factors. Also it suggested that the processing treatments to which the kariya seed was subjected to had no major reducing effects on the toxic substance(s) [32]. The values of the anti-nutritional factors are reported in another study underway. The mortality rate during the experiment is shown in Figure 4. The food intake and changes in the body weights may be influenced by the source of nitrogen and this was in accordance with the report of Obizoba [33] that the food intake and the changes in the body weights were influenced by the source of nitrogen and varietal differences in raw kariya and protein concentrate which were combined with acha.

\section{The protein efficiency ratio (PER) and food efficiency ratio} (FER)

The Protein Efficiency Ratio (PER) and Food Efficiency Ratio (FER) results are presented in Figure 5. The PER ranged between -1.55 (ASD) and 1.85 (commercial diet). PER for ACD (80\% acha $+20 \%$ kariya protein concentrate) and ARD $(80 \%$ acha $+20 \%$ raw kariya $)$ could not be calculated because of the death of all the animals fed with the diets. From the results, it was observed that the PER was less than 2.5 which is regarded as the baseline for PER meant for weaning food. The PER gives indication of how well the protein has been effectively utilized by the animals. The lower PER signified that the diets did not support growth. ASD (100\% acha) had low PER because it is deficient in some essential amino acids like lysine which might be responsible for the decline in the growth rate [7].

The FER ranged from -0.24 to 0.28 . FER follows similar trend with the PER. The control diet had the highest FER (0.28) while the basal had the lowest FER (-0.24).

Table 2: Food intake of the experimental animals at the end of feeding experiment.

\begin{tabular}{|l|l|l|}
\hline Dietary samples & Food Intake (g/rat/28 days) & $\begin{array}{l}\text { Mean weight gained } \\
(\mathrm{g} / \text { rat/28 days) }\end{array}$ \\
\hline Basal & 0 & 0 \\
\hline ACD & 0 & 0 \\
\hline ARD & 0 & 0 \\
\hline ABD & $104.46 \pm 4.97$ & -25.44 \\
\hline AED & $196.86 \pm 8.00$ & -15.88 \\
\hline ASD & $133.58 \pm 3.48$ & 55.72 \\
\hline
\end{tabular}

Mean values in the same column followed by different superscripts are significantly different at $\mathrm{p} \geq 0.05$

ARD: $80 \%$ Acha $+20 \%$ raw kariya flour; ACD: $80 \%$ Acha $+20 \%$ kariya protein concentrate; ABD: Basal; AED: Commercial Diet (Control); ASD: $100 \%$ Acha.

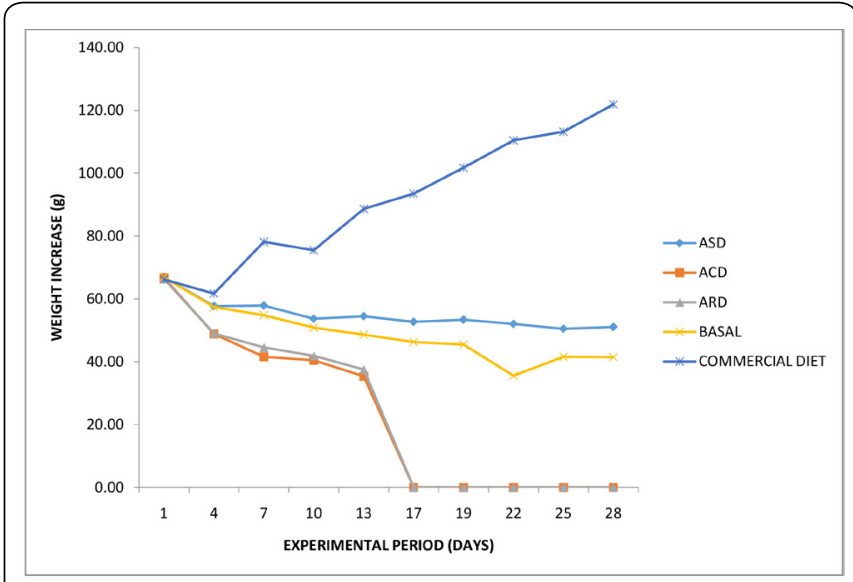

Figure 3: Growth rate of the experimental animals fed with the formulated diets and control. ACD: $80 \%$ Acha $+20 \%$ kariya Protein Concentrate; ARD: $80 \% A c h a+20 \%$ Raw kariya; ASD: $100 \%$ Acha.

True digestibility, net protein retention and protein retention efficiency

The true digestibility (TD) of the formulated diets is shown in Table 3 and it varied from 54.26\% (commercial diet) to $62.89 \%$ (ASD). $100 \%$ acha had better digestibility than the commercial diets. Iwe [34] reported that legumes and oilseeds had reduced digestibility. This was attributed to the presence of anti-nutritional factors like tannins. It was also reported in the study that phenolic compounds like tannins exert influence by binding with various compounds including protein and making them less available to the animal because as dietary tannin content increase; the digestibility, energy and protein in the diet also decreases. Apart from the presence of 
anti-nutritional factor that reduces the protein digestibility, large intakes of dietary fibre, especially hemicelluloses increase the excretion of nitrogen in the feces, reducing the apparent protein digestibility of about $10 \%$ [29].

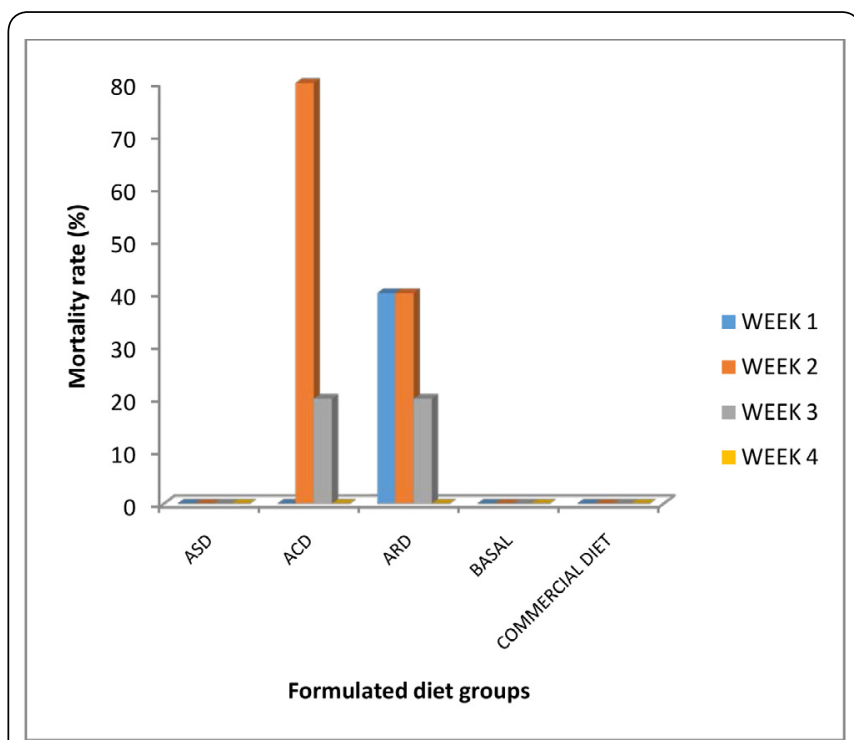

Figure 4: Mortality rate during the experimental period.

ACD: $80 \%$ Acha $+20 \%$ kariya Protein Concentrate; ARD: $80 \% A c h a+20 \%$ Raw kariya; ASD: $100 \%$ Acha.

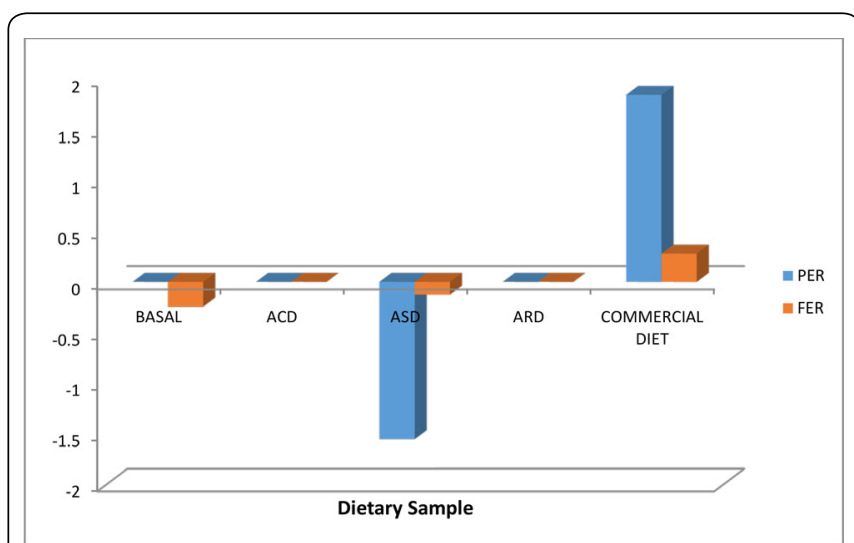

Figure 5: Protein Efficiency Ratio (PER) and Food Efficiency Ratio (FER) of the formulated diets.

ACD: $80 \%$ Acha $+20 \%$ kariya Protein Concentrate; ARD: $80 \%$ Acha $a+20 \%$ Raw kariya; ASD: 100\% Acha.

The NPR (Table 3) of the diet ranged from -4.04 (ASD) to 1.00 (commercial diet). The most favorable value was apparent in group fed with commercial diet whereas NPR is inferior in group receiving ASD. TD is a measure of the digestibility of food protein and the biological value of the amino acid mixture absorbed from food [35]. The PRE (Table 3) followed similar trend as observed in NPR values.

\section{Weight of various tissues of the experimental animals}

The mean weights of liver (Table 4) of the rats ranged from $2.10 \mathrm{~g}$ (basal diet) to $4.88 \mathrm{~g}$ (commercial diet). The sizes of the organs under consideration are related to the body weight of the experimental animals. The kidney size ranged from $0.53 \mathrm{~g}$ (basal diet) to $1.18 \mathrm{~g}$ (commercial diet). Generally, the tissues collected from the animals fed on basal diet were found to be very small and indeed much smaller than those of animals from other experimental groups which were due to protein deficiency in the diet. The weights of kidney and muscle tissues in the groups followed the same trend as that of the liver.

Table 3: Nutritional values of experimental diets compared with control diets.

\begin{tabular}{|l|l|l|l|}
\hline Samples & TD & NPR & PRE \\
\hline Basal & 0 & 0 & 0 \\
\hline ACD & 0 & 0 & 0 \\
\hline ARD & 0 & 0 & 0 \\
\hline ASD & 62.89 & -4.04 & -64.61 \\
\hline Commercial diet & 54.26 & 1.00 & 16.06 \\
\hline
\end{tabular}

ACD $80 \% A c h a+20 \%$ kariya Protein Concentrate; ARD: $80 \% A c h a+$ 20\% Raw kariya; ASD: 100\% Acha; TD: True digestibility; NPR: Net protein ratio; PRE: Protein efficiency ratio.

\section{Total nitrogen in the tissues of the experimented animals}

The total nitrogen in the tissues of the rats during the experimental period is shown in Figure 6. The mean total nitrogen of the tissues of the experimental animals followed the same trends as that of the weight of the tissues. There was increase in tissue (liver, kidney and plantaris muscle) nitrogen content in the group of animals fed the commercial diet compared to the other diets. The result observed might be as a result of the amount of the food consumed and subsequent nitrogen absorbed by the experimental animals.

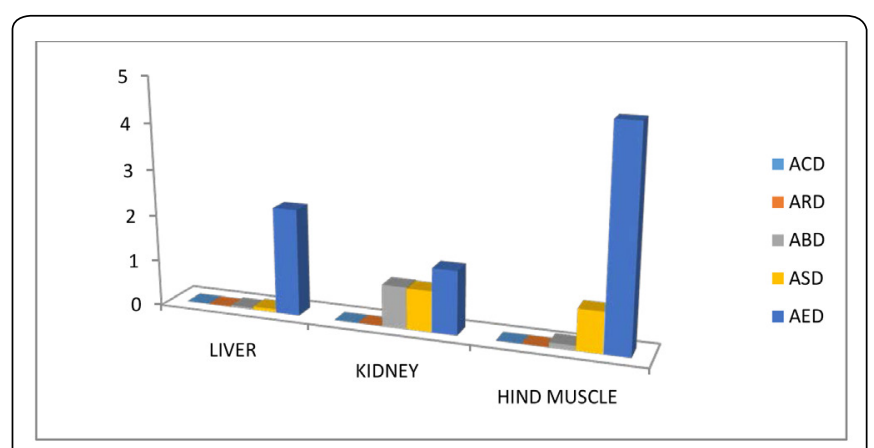

Figure 6: Total nitrogen in tissues of rats during the experimental period. ABD: Basal; ACD: $80 \%$ Acha $+20 \%$ kariya Protein Concentrate; AED: Commercial Diet (Control); ARD: $80 \% A c h a+20 \%$ Raw kariya; ASD: $100 \%$ Acha.

\section{Conclusion}

This study concluded that there was a significant decline in growth and nutritional status of experimental animals fed with acha-kariya based complementary diets. The acha-kariya diets did not support healthy living in the animals. There was decline in their growth rate until they all died after the $13^{\text {th }}$ day of the feeding exercise. The $100 \%$ acha diet gave lower values of PER, FER, NPR and PRE than the commercial diet. It showed that acha should be complemented with other protein rich foods. Moreover, the study concluded that despite the high nutritional value and decrease in anti-nutrients contents of kariya flour after series of processing, the blends were still 
lethal to the experimental animals; the diets containing kariya may not be safe for infant except thorough detoxification is ensured.

Table 4: Total weight of selected tissues of rats $(\mathrm{g})$ during the experimental period.

\begin{tabular}{|l|l|l|l|}
\hline Dietary samples & Liver & Kidney & Muscle (plantaris) \\
\hline Stabilizing diet & $3.25 \pm 0.42$ & $0.75 \pm 0.11$ & $0.82 \pm 0.12$ \\
\hline ABD & $2.10 \pm 0.13$ & $0.53 \pm 0.08$ & $0.38 \pm 0.18$ \\
\hline AED & $4.88 \pm 0.25$ & $1.18 \pm 0.11$ & $0.85 \pm 0.48$ \\
\hline ASD & $3.11 \pm 0.10$ & $0.65 \pm 0.12$ & $0.51 \pm 0.07$ \\
\hline
\end{tabular}

Mean values in the same column followed by different superscripts are significantly different at $\mathrm{p} \leq 0.05$

ABD: Basal; AED: Commercial Diet (Control); ASD: 100\% Acha.

\section{Conflict of Interest}

There is no conflict of interest. There is no impending conflict of interest as far as this study is concerned.

\section{References}

1. Fashakin JB, Olanrewaju I, Ilori MO. 1991. Preparation of an infant weaning food by the application of linear programming and the use of protein from plant sources in the proceedings of seminar on development of high protein energy foods from grain legumes.

2. NDHS. 2013. Nigeria demographic and health survey. National Population Commission, Abuja, Nigeria, and Rockville, Maryland, USA: NPC and ICF International.

3. Ojofeitimi EO. 1982. Causes of protein energy malnutrition as viewed by the client's mother. J Trop Pediatr 28(3): 147-148. doi: 10.1093/ tropej/28.3.147

4. Ikujenlola AV, Fashakin JB. 2005. Bioassay assessment of a complementary diet prepared from vegetable proteins. J Food Agri Environ 3(3-4): 20-22.

5. Fashakin JB. 2006. Bioassay and physico-chemical properties of a complementary food prepared from cowpea (Vigna unguiculata) and melon seeds as main sources of proteins. Proceedings of $2^{\text {nd }}$ Annual Conference. School of Agriculture and Technology, Federal University of Technology, Akure, Nigeria.

6. Adepeju AB, Gbadamosi SO, Omobuwajo TO, Abiodun OA. 2014. Functional and physico-chemical properties of complementary diets produced from breadfruit (Artcarpus altilis). African Journal of Food Science Technology 5(4): 105-113. doi: 10.14303/ajfst.2014.031

7. Abiose SH, Ikujenlola AV, Abioderin FI. 2015. Nutritional quality assessment of complementary foods produced from fermented and malted quality protein maize fortified with soybean flour. Pol J Food Nutr Sci 65(1): 49-56. doi: 10.1515/pjfns-2015-0004

8. Lalude LO, Fashakin JB. 2006. Development and nutritional assessment of a weaning food from sorghum and oil-seeds. Pakistan Journal of Nutrition 5(3): 257-260. doi: 10.3923/pjn.2006.257.260

9. Ijarotimi OS, Aroge F. 2005. Evaluation of nutritional composition, sensory and physical properties of a potential weaning food from locally available food materials breadfruit (Artocarpus altilis) and soybeans (Glycine max). Pol J Food Nutr Sci 55(4): 411-415.

10. Ijarotimi OS, Bakare SS. 2006. Evaluation of proximate, mineral and anti-nutritional factor of home processed complementary diets from locally available food materials (Sorghum bicolour and Sphenostylis stenocarpa). Journal Food Technology 4(4): 339-344.

11. Anuonye JC, Onuh JO, Egwin E, Adeyemo SO.2010. Nutrient and anti- nutrient composition of extruded acha/soybean blends. J Food Process Preserv 34(S2): 680-691. doi: 10.1111/j.1745-4549.2009.00425.x

12. Tizazu S, Urga K, Abuye C, Retta N. 2010. Improvement of energy and nutrient density of sorghum based complementary foods using germination. African Journal of Food, Agriculture, Nutrition, and Development 10(8): 2927-2942. doi: 10.4314/ajfand.v10i8.60875

13. Olapade AA, Aworh OC. 2012. Chemical and nutritional evaluation of extruded complementary foods from blends of fonio (Digitaria exilis stapf) and cowpea (Vigna unguiculata L. Walp) flours. International Journal of Food Nutritional Science 1(3): 4-8.

14. Ugwuona FU, Awogbeja MD, Ogara JJ. 2012. Quality evaluation of Soy-acha mixes for infant feeding. Indian J Sci Res 3(1): 43-50.

15. Ukegbu PO, Anyika JU. 2012. Chemical analysis and nutrient adequacy of maize gruel ( $p a p)$ supplemented with other food sources in Ngorokpala LGA, Imo state, Nigeria. Journal of Biology, Agriculture and Healthcare 2(6):13-20.

16. Ijarotimi SO, Keshinro OO. 2013. Determination of nutrient composition and protein quality of potential complementary foods formulated from the combination of fermented popcorn, African locust and Bambara groundnut seed flour. Pol J Food Nutr 63(3): 155-166. doi: $10.2478 / \mathrm{v} 10222-012-0079-\mathrm{z}$

17. Ikujenlola AV, Oguntuase SO, Omosuli SV. 2013. Physico-chemical properties of complementary food from malted quality protein maize (Zea mays L.) and defatted fluted pumpkin flour (Telfairia occidentalis Hook. F.). Food and Public Health 3(6): 323-328. doi: 10.5923/j. fph.20130306.09

18. Ikujenlola AV. 2014. Chemical and functional properties of complementary food blends from malted and unmalted acha (Digitaria exilis), soybean (Glycine max) and defatted sesame (Sesamun indicum L.) flours. African Journal of Food Science 8(7): 361-367. doi: 10.5897/ AJFS2014.1173

19. Dewey KG, Brown KH. 2003. Update on technical issues concerning complementary feeding of young children in developing countries and implications for intervention programs. Food Nutrition Bulletin 24(1): 5-28.

20. NRC. 1996. Grains. Fonio (acha). In: Lost crops of Africa, Volume 1. National Academy Press, National Research Council Washington, DC, USA, pp 59-75.

21. Jideani IA. 1999. Traditional and possible technological uses of Digitaria exilis (acha) and Digitaria iburua (iburu): a review. Plant Foods Hum Nutr 54(4): 363-374. doi: 10.1023/A:1008193503688

22. Obizoba IC, Anyika JU. 1994. Nutritive value of baobab milk (gubdi) and mixtures of baobab (Adanosonia digitata L.) and hungry rice, acha (Digitaria exilis) flours. Plant Foods Hum Nutr 46(2): 157-165. doi: 10.1007/BF01088768

23. Irvine FR. 1961. Woody plants of Ghana. Oxford University Press. London, UK, pp. 172-174.

24. Hildergadia Notes. 2007.

25. Inglett GE, Cavins JF, Spencer GF. 1973. Seed compositions of Hildegardia barterii. Econ Bot 27(1): 128-130. doi: 10.1007/ BF02862225

26. Cheftel JC, Cuq JL, Lorient D. 1985. Amino acids, peptides and proteins. In: Damodaran S (ed) Fennema Food Chemistry. Marcel Deeker Inc, New York, USA, pp 327-328.

27. Gbadamosi SO, Abiose SH, Aluko RE. 2012. Amino acid profile, protein digestibility thermal and functional properties of Conophor nut (Tetracarpidium conophorum) defatted flour, protein concentrate and isolates. Int J Food Sci Technol 47(4): 731-739. doi: 10.1111/j.13652621.2011.02901.x

28. PAG. 1971. Protein Advisory Group of the United Nation. Guideline No.8. Food and Agriculture Organization of the United Nation/World Health Organization/United Nation Children Funds. New York, USA, pp 1-7. 
29. FAO/WHO/UNU. 1985. Energy and protein requirements. Report of a joint $\mathrm{F}$ AO/WHO/UNU export consultation. World Health Organ Tech Rep Ser 724: 1-206.

30. Ikujenlola AV, Adurotoye EA. 2014. Evaluation of quality characteristics of high nutrients dense complementary food from mixtures of malted quality maize (Zea mays L.) and steam cowpea (Vigna ungiculata).J Food Process Technol 5: 291. doi: 10.4172/2157-7110.1000291

31. Vavidel V, Pugalenthi M. 2007. Biological value and protein quality of raw and processed seeds of Mucuna pruriens var. utilis. Livestock Research for Rural Development 70: 16-24.

32. Gbadamosi SO, Famuwagun AA. 2016. Studies on the proximate, anti- nutritional and antioxidant properties of fermented and unfermented kariya (Hildergardia barterii) seed protein isolates.J Food Process Technol 7: 618. doi: 10.4172/2157-7110.1000618.

33. Obizoba IC. 1991. Effect of sprouting on the nitrogenous constituents and mineral composition of pigeon pea (Cajanus cajan) seed. Plant Foods Hum Nutr 41(1): 21-26. doi: 10.1007/BF02196378

34. Iwe MO. 2003. The science and technology of soybean: chemistry, nutrition, processing and utilization. Rojoint Communication Services Ltd. Enugu, Nigeria, pp 115-146.

35. Ihekoronye AI, Ngoddy PO. 1985. Integrated food science and technology for the tropics. Macmilllan Publishers, London, UK. 